\title{
Two New Species of Pectis (Asteraceae: Tageteae) from South America
}

\author{
David J. Keil \\ Biological Sciences Department, California Polytechnic State University, San Luis Obispo, \\ California 93407, U.S.A. dkeil@calpoly.edu
}

Abstract. Pectis hassleri and P. pumila are new species, the former from the Gran Chaco area of Paraguay and the latter from southwestern Ecuador and northwestern Peru. Pectis hassleri differs from $P$. odorata by leaves that are glandular-punctate on the adaxial as well as the abaxial surfaces, by longer and wider ligules of the ray florets, and by ray pappi of awns and shorter bristles. Pectis pumila differs from the closely related $P$. arida by its wider leaves and by its sessile or subsessile capitula with campanulate involucres and obovate phyllaries. A hexaploid chromosome count of $2 n=36_{\text {II }}$ is newly reported for $P$. pumila.

Key words: Asteraceae, Compositae, Ecuador, Paraguay, Pectis, Peru, South America, Tageteae.

As part of monographic studies of Pectis L. (Asteraceae: Tageteae), I have discovered two previously undescribed South American species.

Pectis hassleri Keil, sp. nov. TYPE: Paraguay. Gran Chaco: Loma Clavel, $23^{\circ} 20^{\prime} \mathrm{S}$, Nov. 1903, E. Hassler 2491 (holotype, G; isotypes, BM, F, GH, K, LIL, MICH, MO, NY, P, S, UC, US).

$P$. odoratae affinis sed glandibus pellucidis numerosis in lamina adaxiali, ligulis flosculorum radiorum longioribus (5.5-6.5 mm vs. $3-4 \mathrm{~mm}$ ) et latioribus, et pappis acheniorum radiorum $2-3$ aristarum $2.5-4 \mathrm{~mm}$ longum et ca. 10 setarum breviorum versus $30-40$ setarum usque ad $7 \mathrm{~mm}$ longum diversa.

Annual or sometimes apparently perennial; herbage probably scented, but nature of odor unknown. Stems spreading to erect or ascending, 10-35 cm long, several-branched from near the base, fewbranched above, moderately to densely leafy, purple-brown, glabrous or sparsely to densely puberulent. Leaves opposite, lance-linear, often falcate, $2-5 \mathrm{~cm}$ long, 2-4 $\mathrm{mm}$ wide, acute, mucronate to bristle-tipped, proximally ciliate with 2 to 5 pairs of bristles 2-3 mm long, glabrous or sparsely distally scaberulous on the margins, densely dotted on both surfaces with round, pellucid glands 0.1-0.2 $\mathrm{mm}$ diam., the glands of the adaxial surface smaller and more numerous than those of the abaxial surface, minutely ciliolate near the base, otherwise glabrous. Capitula long-peduncled, solitary or in open, few-headed cymes, ca. 38- to 75-flowered; peduncles $3-11 \mathrm{~cm}$ long, slightly clavate, bearing 3 to 7 linear-acuminate scale-like bractlets $3-6 \mathrm{~mm}$ long or the proximal bract larger and leaflike. Involucres campanulate; phyllaries 8 (to 10), oblanceolate to obovate, $6-8.5 \times 2-3.5 \mathrm{~mm}$, broadly overlapping, subacute, weakly convex, proximally rounded and gibbous, indurate-keeled in the proximal $1 / 2-2 / 3$, narrowly hyaline- or purple-margined in the proximal $2 / 3$, densely dotted or streaked with elliptical to linear glands, distally ciliolate. Ray florets 8 (to 10); corolla yellow or reddening abaxially, 9-10 mm long, the tube 3-3.5 mm long, the ligule narrowly ovate, $5.5-6.5 \mathrm{~mm}$ long, glabrous. Disk florets 30 to 65 ; corolla yellow, 4-6 mm long, weakly 2-lipped, slightly exceeding the pappus, the tube and throat about equal, the abaxial lip ca. $1 \mathrm{~mm}$ long. $2-3 \times$ as long as the 4 lobes of the adaxial lip; anthers ca. $2 \mathrm{~mm}$ long; style exserted. Achenes 3.5-4 mm long, sparsely appressed-puberulent with trichomes $0.2-0.4 \mathrm{~mm}$ long; ray pappus of 2 or 3 stiff awns $2.5-4 \mathrm{~mm}$ long and ca. 10 shorter bristles 1-2 mm long; disk pappus of 20 to 30 slender bristles 2-5 mm long. Chromosome number unknown.

Distribution. Endemic to the Gran Chaco area of Paraguay, this species is represented by only a handful of collections with rather sparse data. I have not been able to determine a precise location for any of the collections examined. Elevation data are unavailable. Essentially nothing is known about the ecology of the species. Known flowering dates range from November to June.

Relationships. Pectis hassleri is one of the very few species of Pectis with glands on the adaxial leaf surface. In most other species the glands are confined to the abaxial surface of the leaf or to the margins. The significance, if any, of these extra glands is unknown. The glands are similar in size and shape to those of the related $P$. odorata A. H. R. Grisebach and P. substriata H. H. Rusby, both

Novon 12: 471-473. 2002. 
of which are strongly scented. Presumably P. hassleri is scented as well.

I have named the species in honor of Erich Hassler, a pioneer in botanical studies of Paraguay. Hassler recognized the type collection of $P$. hassleri as a distinct taxon and considered it to be a variety of $P$. odorata. He assigned it an unpublished varietal epithet alluding to broad ligules.

Paratypes. PARAGUAY. Chaco septentrionalis, Puerto Tolancera, 1907, K. Fiebrig 1330 (G); Chaco, $21^{\circ} \mathrm{S}$ lat., 1906, K. Fiebrig 1459 (G, Z); Gran Chaco, s.d., A. Pride s.n. $(\mathrm{K})$; in region crossed by the lower portion of the River Pilcomayo, June 1906, T. Rojas 257 (BAF, BM, $\mathrm{G}, \mathrm{K}, \mathrm{P}$ )

Pectis pumila D. J. Keil, sp. nov. TYPE: Peru. Lambayeque: along Pan American Hwy. ca. 30 $\mathrm{km} \mathrm{NNW}$ of Piura, $7 \mathrm{~km} \mathrm{~S}$ of Puente Sullana (over Río Chira), 30 Mar. 1987, D. J. Keil et al. 19917 (holotype, F; isotypes, ASU, BM, CPUN, F, G, GH, HUT, K, MEXU, MO, NY, OBI, OS, RSA, S, TEX, UC, US, USM).

P. aridae D. J. Keil affinis sed foliis saepe latioribus, capitulis sessilibus vel subsessilibus, involucris campanulatis, et phyllariis obovatis diversa.

Erect or diffusely branched, often strongly scented, tap-rooted annuals. Stems 1 to several from the base, erect or diffusely spreading, 3-50 cm long. cymosely branched distally, straw-colored to dark purple-brown, puberulent throughout or in lines extending from the connate flange and midribs of the leaf bases with soft, multicellular trichomes 0.1$0.2 \mathrm{~mm}$ long. Leaves opposite, linear-oblanceolate or lanceolate, 2-4 cm long, 2-6 mm wide, obtuse to subacute, mucronate or bristle-tipped, with the base narrowed or more often conspicuously expanded, entire and ciliate to beyond the middle with slender bristles 2-4 mm long or serrate with bristle-tipped teeth, punctate abaxially with scattered, round, pellucid glands $0.2-0.3 \mathrm{~mm}$ diam., scaberulous along the margins, sparsely hirtellous proximally along the margin and midrib with trichomes $0.1-0.2 \mathrm{~mm}$ long, otherwise glabrous. Capitula solitary, sessile or subsessile in the forks of the stems, subtended by 1 or 2 scarious, lanceacuminate bractlets, 24- to 31-flowered. Involucres campanulate; phyllaries 5 or 6 , obovate, broadly overlapping, 5-7 $\times 2.5-4 \mathrm{~mm}$, obtuse to subacute, mucronulate, broadly scarious-margined, broadly convex and inconspicuously round-keeled, distally sparsely punctate with 1 to several elliptic glands $0.2-0.3 \mathrm{~mm}$ long, sometimes streaked proximally with linear glands or occasionally glandless, eroseciliolate at the apex, otherwise glabrous. Ray florets 5 or 6 ; corolla yellow or becoming pink, 4-5 mm long, the tube 1.5-2 $\mathrm{mm}$ long, the ligule slender, 2.5-3 mm long, glabrous. Disk florets 19 to 25; corolla yellow, weakly 2-lipped, glabrous or glandular-puberulent, $2.5-3.5 \mathrm{~mm}$ long, the tube 0.8 $1 \mathrm{~mm}$ long, the throat $0.6-1.2 \mathrm{~mm}$ long, the abaxial lip 1-1.3 mm long, $2-3 \times$ as long as the 4 lobes of the adaxial lip; anthers ca. $1 \mathrm{~mm}$ long; style about as long as the corolla, included. Achenes 2.7-3.8 $\mathrm{mm}$ long, strigillose with 2-celled hairs $0.2-0.3 \mathrm{~mm}$ long. Ray pappus of 1 or 2 paleaceous-based, antrorsely barbed bristles $2-2.5 \mathrm{~mm}$ long or sometimes reduced to scales $0.5 \mathrm{~mm}$ long or shorter, sometimes with 1 or 2 additional scales between the bristles. Disk pappus of 15 to 25 unequal paleaceous-based, antrorsely barbed bristles 1.5-4 $\mathrm{mm}$ long. Chromosome number: $2 n=36_{\mathrm{II}}$.

Distribution. Pectis pumila occurs only in the coastal lowlands of southern Ecuador and northern Peru at 0-250 m. Habitats include arid scrublands, roadsides, and beaches. It often occurs in mixed populations with the closely related Pectis arida and with P. linifolia L. var. linifolia. Some herbarium specimens have mixed gatherings of $P$. arida and $P$. pumila. In beach habitats $P$. pumila grows in proximity to $P$. multiflosculosa (DC.) C. H. Schultz Bipontinus.

Relationships. Pectis pumila is apparently most closely related to $P$. arida. Both are much-branched annuals with leaves densely gland-dotted abaxially. The sessile or subsessile campanulate capitula with broad phyllaries differentiate $P$. pumila from $P$. ar$i d a$, which has peduncled capitula with cylindrical involucres and narrower phyllaries.

This species has been collected for many years, but it either has gone undetermined in herbaria or has been misidentified. Until recently, I believed it to be the taxon described by H. Cassini (1819) as Cryptopetalon ciliare (Pectis cryptopetala C. H. Schultz Bipontinus). I now know that the type (P) for that name is conspecific with the type of Pectis sessiliflora (Lessing) C. H. Schultz Bipontinus. Because the specific epithet used by Cassini when he described the taxon as a member of the genus Cryptopetalon is the same as that of a Linnaean species of Pectis, many botanists have misidentified P. pumila as Pectis ciliaris L., a very different taxon not known from western South America.

Chromosome number. A meiotic chromosome number of $2 n=36_{\text {II }}$ (diakinesis) was determined from Keil et al. 19917-D (OBI) and is herein newly reported. The well-established base number for Pectis is $x=12$ (Keil, 1977; Keil et al., 1988). Pectis pumila is therefore a hexaploid taxon. 
Paratypes. ECUADOR. Guayas: Salinas, 7 Apr. 1939, E. Asplund 5620 (S); Salinas, Puntilla, 1 May 1956, E. Asplund 20369 (S); along Pacific Ocean betw. Santa Elena \& San Pablo, 17 Mar. 1973, L. Holm-Nielsen et al. 2082 (S); Chanduy, 18 Mar. 1973, L. Holm-Nielsen et al. 2118 (COL, F, NY, S); Punta de Santa Elena, 21 Mar. 1973, L. Holm-Nielsen et al. 2306 (F, MO, NY, S, U), 2309 (MO, NY, S), 2337 (NY, S), 2356 (F, MO, NY, S, U); Ancón Distr., Santa Elena Peninsula, 7 June 1932, Sheppard s.n. (K); Chanduy, R. Spruce 6476 (BM, E, G, K, LE, OXF), 6477 (BM, G, OXF, P); Salinas, Puntilla, 1-2 Mar. 1941, H. K. Svenson 11078 (US), 11096 (GH, US); Salinas, Puntilla, 21 Feb. 1941, H. K. Svenson 11124 p.p. [mixed with $P$. arida] (US); Salinas, 15 Mar. 1941, H. K. Svenson 11208 (GH, NY, US); Punta Centinela, 6 Apr. 1941, H. K. Svenson 11267 (NY); Punta Carnero, Peninsula de Santa Elena, May 1978, F. M. Valverde 2569 (MO). PERU. Lambayeque: near Motupe, 18 Apr. 1953, $R$. Ferreyra 9084 (MO, OBI, USM); $24 \mathrm{~km} \mathrm{~S}$ of Motupe, 29 Mar. 1987, D. J. Keil et al. 19911 (F, MO, OBI, UC). Piura: El Alto, 14 May 1957, H. Ellenberg 1388 (U); Piura, betw. Amotape \& Talara, 19 Apr. 1949, R. Ferreyra 5935 p.p. [mixed with P. arida] (US); Quebrada Mogollon, Amotape hills, 29 Mar. 1941, O. Haught \& H. K. Svenson 11520 p.p. [mixed with $P$. arida] (NY); E of La Brea, 25 km SE of Talara, 3 Mar. 1939, O. B. Horton 11581 (G, GH, UC); $39 \mathrm{~km} \mathrm{NW}$ of Marca Vellica, 30 Mar. 1987, D. J. Keil et al. 19920 (CPUN, F, HUT, MO, NY, OBI, OS, TEX, UC, USM); betw. Talara \& Los Organos, 30 Mar. 1987, D. J. Keil et al. 19923 (OBI); Talara, s.d., E. Smith 15 (MO, USM, OBI); Huancabamba, Serrán, 2 Apr. 1939, H. E. Stork 11368 p.p. [mixed with $P$. arida] $(\mathrm{GH})$. Tum- bes: $\mathrm{N}$ of Tumbes, 7 May 1957, H. Ellenberg $1276(\mathrm{U})$ Caleta Cruz betw. Zorritos \& Tumbes, 27 May 1957, R. Ferreyra 12220 (MO); Caleta Cruz, 25 Apr. 1955, R. Ferreyra et al. 10694 p.p. [mixed with $P$. arida] (OBI, USM); beach just $\mathrm{S}$ of Cancas, 30 Mar. 1987, D. J. Keil et al. 19925 (ASU, BM, CPUN, F, G, GH, HUT, K, MO, NY, OBI, RSA, S, UC, US, USM); beach $2 \mathrm{~km} \mathrm{~N}$ of Cancas, 30 Mar. 1987, D. J. Keil et al. 19929 (CPUN, F, HUT, MO, OBI, USM).

Acknowledgments. Research was supported by National Science Foundation Grant DEB 81-04683 and a minigrant from California Polytechnic State University. I am grateful to the curators of the cited herbaria for the loan of material and/or hospitality during herbarium visits. I am indebted to Charles and Lizbeth Burandt with whom I shared Peruvian adventures.

Literature Cited

Cassini, H. 1819. Cryptopétale, Cryptopetalon. P. 123 in F. Cuvier, Dictionnaire des Sciences Naturelles, 2nd ed., vol. 12. Paris.

Keil, D. J. 1977. Chromosome studies in North and Central American species of Pectis (Compositae: Tageteae). Rhodora 79: 79-94.

— M. A. Luckow \& D. J. Pinkava. 1988. Chromosome studies in Asteraceae from the United States, Mexico, the West Indies, and South America. Amer. J. Bot. 75: 650-666. 